\title{
Determining Factors of Subsidiary Development
}

\author{
Pedersen, Torben
}

Document Version

Final published version

Publication date:

2006

\section{License \\ CC BY-NC-ND}

Citation for published version (APA):

Pedersen, T. (2006). Determining Factors of Subsidiary Development. Center for Strategic Management and Globalization.

Link to publication in CBS Research Portal

\section{General rights}

Copyright and moral rights for the publications made accessible in the public portal are retained by the authors and/or other copyright owners and it is a condition of accessing publications that users recognise and abide by the legal requirements associated with these rights.

\section{Take down policy}

If you believe that this document breaches copyright please contact us (research.lib@cbs.dk) providing details, and we will remove access to the work immediately and investigate your claim. 
Determining Factors of Subsidiary

Development

Torben Pedersen

SMG WP 4/2006

January 2006 
SMG Working Paper No. 4/2006

January 2006

ISBN: 87-91815-20-7

Center for Strategic Management and Globalization Copenhagen Business School

Porcelænshaven 24

2000 Frederiksberg

Denmark

www.cbs.dk/smg 


\title{
Determining Factors of Subsidiary Development
}

\author{
Torben Pedersen \\ Copenhagen Business School \\ Center of Strategic Management and Globalization \\ Porcelænshaven 24 \\ DK-2000 Frederiksberg \\ Email: tp.int@cbs.dk
}

\begin{abstract}
Subsidiary development is a multi-dimensional construct that cannot be captured just by looking at subsidiary roles, activities, etc. Three distinct dimensions of subsidiary development are identified and these are: scope of subsidiary (the breadth of activities), level of subsidiary competence (the depth of activities) and level of integration in the internal MNC-network. Birkinshaw and Hood (1998a) have in their seminal paper proposed a model where subsidiary development is determined by three factors: Headquarter assignment, dynamism of local business environment and subsidiary initiatives. This paper is the first to conduct a statistical test of this model on a large-sample data set including data of more than 2.100 subsidiaries located in seven different countries in Europe. The effect of the three determining factors on subsidiary development is tested simultaneously in a LISREL model.
\end{abstract}




\subsection{Introduction}

The literature on subsidiary development has greatly expanded over the last twenty years, evaluating the dynamics behind the evolution of subsidiary roles. The literature emerged out of a critique of the traditional 'centre-periphery' view where the firm-specific advantages are developed and controlled by the parent company, while the foreign subsidiaries are the long-arm of the parent company in exploiting the firm-specific advantages in the local market. The observation that some subsidiaries have a strategic role in the multinational corporation (MNC) that reaches beyond their local undertakings (e.g. Etemad and Dulude, 1986; Bartlett and Ghoshal, 1989; Gupta and Govindarajan, 1994) was the starting point of research on different subsidiary roles and the evolution of subsidiary roles.

A common understanding in recent literature is that MNCs consists of dynamic network of more or less specialized subsidiaries linked to each other in multiple, complex patterns. It is generally argued that the new picture reflect the response of the MNCs to increasing global competition and rapid technological development, and a consequent shift in focus from exploitation of firm-specific advantages (Hymer, 1960; Buckley and Casson, 1976; Hennart, 1982) to global accumulation and dissemination of knowledge within MNCs (Kogut, 1993; Malnight, 1996, Doz et. al. 2001). An important element in the new picture is that some subsidiaries are specialized in certain skills, capabilities or fields of operations of importance for the whole corporation and are therefore gaining a more strategic role than other subsidiaries. This process of subsidiaries enhancing their resources and competences is denoted 'subsidiary development'.

Subsidiary development is an important phenomenon for several reasons. The first is that multinational corporate evolution is driven in large part by the changes that are exhibited in its foreign subsidiaries. The process of subsidiary development is itself indicative of the much discussed trend towards greater international dispersal of value-adding activities in MNCs. The second reason is that the subsidiary draws from and contributes to the development of the economy of its host country. Much has been written about the importance of technological spillovers from foreign direct investment (FDI) and how subsidiaries are building relationships with local counterparts and tapping into local clusters in various ways. Clearly, in countries where foreignowned subsidiaries make up a large part of the industrial sector, the phenomenon of subsidiary 
development is not an academic exercise - it lies at the heart of fundamental economic questions such as national competitiveness, investment attraction and job creation.

The present paper will explore the factors determining subsidiary development and provide at better understanding of which factors that matter for different dimensions of subsidiary development. A central questions is to what extent is subsidiary development determined by the MNC headquarter vs. own subsidiary initiative? And how important are the dynamism of the local business environment (e.g. leading-edge clusters or other favorable conditions) for subsidiary development? The policy implications follow from the insights on how the different factors are influencing subsidiary development, which provide guidance on how policy makers can target their efforts in order to facilitate upgrading and development of the foreign owned subsidiaries.

\subsection{Subsidiary Development}

Historically, MNEs used their subsidiaries abroad mainly for the purpose of the adaptation of products developed in their home countries to local tastes or customer needs, and the adaptation of processes to local resource availabilities and production conditions. In this case subsidiaries were dependent on the competence of their parent companies, and accordingly their role was essentially 'home-base exploiting' (Kuemmerle 1999). In recent years instead, linked to the closer integration of subsidiaries into international networks within the MNE, some subsidiary operations have gained a more creative role, e.g., to generate new technology in accordance with the comparative advantage in innovation of the country in which the subsidiary is located. This transformation has led to subsidiaries gaining new roles in the MNC.

The new subsidiary roles have been expressed in several different terms used to characterize such subsidiaries; world product mandate (Etemad and Dulude, 1986), strategic leader (Bartlett and Ghoshal, 1989), global innovator or integrated player (Gupta and Govindrajan, 1991), and centre of excellence (Holm and Pedersen, 2000). All of these terms point to the fact that, over the past two decades or so, subsidiaries have been evolving out of their traditional role of being the subservient executors of headquarters commands. This process 'through which MNC subsidiaries enhance their resources and capabilities, and in so doing add increasing levels of value to the MNC as a whole' has been called 'subsidiary development' (Birkinshaw and Hood, 1998b). 
In a review of the MNC subsidiary management research three streams of research is identified as shown in Table 2.1 (Birkinshaw and Hood, 1998b). These are the streams of: HQ-subsidiary relationship, subsidiary role and subsidiary development. The basic assumption in the literature on HQ-subsidiary relationship is the hierarchical nature of the $\mathrm{MNC}$ where headquarter delegate decision rights to subsidiaries, in a way so decisions rights are "loaned, not owned"' (Foss and Foss, 2002). Subsidiaries are controlled by headquarter that retains the power of veto, i.e., the ability to overrule any subsidiary decision. This implies that the process of subsidiary development is designed by headquarter and new subsidiary mandates is decided by the parent firm and subsequently given to the subsidiary.

The starting point of the literature stream on subsidiary roles is the recognition that subsidiaries may obtain very different roles in the MNC. The focus is mainly on identification of typologies capturing the various roles of MNC-subsidiaries. A strong emphasis is on the level of subsidiary autonomy and product mandates while issues pertaining to the integration and collaboration with other MNC-units are of minor importance. Product mandates are rather earned than given by headquarter. In this view subsidiary autonomy is based on unique resources and bargaining power, and are, therefore, fundamentally different from discretion in the sense that it is much more difficult for headquarters to revoke. In other words, subsidiaries with some bargaining power and autonomy have a degree of 'ownership' over their decision rights rather than holding them at the pleasure of headquarters.

The subsidiary development stream builds on the network perspective of the MNC and focus more on the evolution of subsidiary activities over time. The MNC is conceptualized as an 'interorganizational network' of loosely coupled entities, rather than a hierarchical monolith. This loose coupling gives the subsidiary freedom to develop its own unique resource profile by linking the internal network of MNC-units and the external network of local counterparts (e.g. key suppliers and customers). The basic idea is that over time the subsidiary accumulates valuable competences through its network relationships, so other MNC-units becomes dependent on their competences, which leads to an enhanced status and an extension of their activities. It reflects the reality that many subsidiaries have specialized competences on which the rest of the MNC is dependent and this allow the subsidiary to take more control of its own destiny (Pfeffer and Salancik, 1978). 
Although, it is recognized that MNE subsidiaries pursue their own interests and are not a mechanical instrument of headquarters' will (Nohria and Ghoshal, 1994), the emphasis are on MNC-interdependence rather than subsidiary autonomy. The subsidiaries are pursuing their own interest by engaging in the internal MNC network (as well as the external network) and using their bargaining power to attract more internal resources from the MNC rather than seeking autonomy and isolating themselves from other MNC-units.

**** Insert Table 2.1 about her ****

One critique that has been forwarded against the literature on subsidiary development is that most studies on subsidiary evolution have only approached the issue from an internal perspective. The subsidiary development is viewed as the result of corporate headquarters assignment or an autonomous process within the subsidiary. However, less attention has been given to the external environment. Although the literature on aggregate economic activity suggests that different roles do evolve, the strategic management literature, with a few exceptions (Benito et. al., 2003), lacks research relating subsidiary development to exogenous factors that are not firm specific.

The external environment can have considerable impact on the scope and competence level of subsidiaries. These are often acknowledged in the literature within the rubric of location advantages. Considerable attention has been paid in the literature to the role of location advantages in determining the initial entry decisions of MNEs in any given market. However, once the decision to enter a given market through FDI is taken, the kinds of activity and the level of competence of the subsidiary are also co-determined by the nature of the location advantages of the host location. The host country's location advantages play an important role in determining the level of competence of the subsidiary. This is on at least two levels. First, the level of competence is a function of the quality of the location advantages that the host location can provide. High competence levels require complementary assets that are non-generic in nature, and are often associated with agglomeration effects, clusters, and the presence of highly specialized skills. In other words, firms are constrained in their choice of high competence subsidiaries by resource availability. For instance, $R \& D$ activities tend to be concentrated in a few locations because the appropriate specialized resources are associated with a few specific locations. Second, MNEs have 
been shown to prefer to engage in sequential investment in locations that may provide sub-optimal returns but with which they have prior experience.

\subsection{Determining Factors}

In the seminal paper by Birkinshaw and Hood (1998a) they argue, based on an extensive literature review, that subsidiary development (or as they put it 'subsidiary evolution') are driven by three factors, namely head-office assignment, subsidiary choice and local environment determinism. These three drivers of subsidiary development are also referring to the three actors that have both vested interests in subsidiary development and the necessary power to influence the process of subsidiary development. These are subsidiary management, parent company management and hostcountry policy-makers. All three actors have an impact on the activities and competences in the subsidiary, which in turn may lead to subsidiary development as shown in Figure 2.1.

Only a few studies have really investigated how these factors affect subsidiary development. One notable exception is the paper by Birkinshaw and Hood (1998b) that explore the model based on a clinical study of thirteen US-owned subsidiaries in Scotland and Canada. But, to our knowledge none have tested the model based on large-sample data, although, a larger quantitative study will permit a test of the general value of the model. In addition, it will make it possible to explore the more interesting questions of the strengths and interaction between the three drivers. E.g. parent company managers and host country policy-makers can either impact the subsidiary activities and resources directly or they can work more indirectly by influencing the actions of subsidiary management. It is an empirical question whether they mainly have a direct or an indirect impact on subsidiary development. However, this is a question with major implications for both policy-makers and parent company managers as it makes an immense difference whether they should target subsidiary development more directly (e.g. through regulation and mandates) or indirectly by influencing the behavior of subsidiary managers.

$* * * *$ Insert Figure 2.1 about here $* * * *$ 


\subsection{Dimensions of Subsidiary Development}

Subsidiary development is obviously a multi-dimensional construct as subsidiaries can develop in many dimensions e.g. in terms of activities, competences, mandates, size. Some authors have proposed a typology of subsidiaries, where subsidiary development is equal to gaining more scope or mandates (e.g. White and Poynter, 1984; Jarillo and Martinez, 1990) that is the breath of activities conducted by the subsidiary. However, as pointed out by Benito et. al. (2003) the subsidiary scope is only one of the relevant dimensions describing subsidiary roles and subsidiary development. Scope and mandates may be very broad or more narrowly focused on specific activities where the subsidiary has a high level of competence. Therefore, scope and mandates alone does not necessarily determine subsidiary roles. Benito et. al. (2003) argue that the level of competence or the depth of subsidiary activities is an important dimension missing when only looking at subsidiary scope. Consequently, it is useful to look at the combination of scope (breath) and competence levels (depth) when discussing subsidiary development.

A third aspect of subsidiary development that has been put forward recently in the literature is the level of MNC-interdependence (Forsgren and Pedersen, 1998). MNC-interdependence is concerned with the extent to which activities that have strategic implications are interrelated and the role played by the focal subsidiary in the internal MNC-network. How important is the focal subsidiary for other MNC-units and do other MNC-units depend on the competences of the subsidiary and vice-versa. The more dependent other MNC-units are on the focal subsidiary the stronger bargaining power and the more resources they will be able to appropriate in the internal MNCnetwork (Holm and Pedersen, 2002).

The final model of subsidiary development that will be tested in the following is then presented in Figure 2.2.

$* * * *$ Insert Figure 2.2 about here $* * * *$

\subsection{Data and Analysis}

The data for this paper was collected as part of the Centres of Excellence-project launched in May 1996 with the purpose of investigating headquarters-subsidiary relationships and the internal flow of knowledge in MNCs. In order to collect comparable quantitative data, a questionnaire that could 
be applied in all the involved countries was constructed. After several project meetings and extensive reliability tests of the questionnaire on both academics and business managers, this was accomplished (For more information on the CoE project, see Holm and Pedersen (2000)).

For practical reasons, each project member was made responsible for gathering data on foreignowned subsidiaries within their own country. Thus, all subsidiaries in the database belong to MNCs. In the data gathering, subsidiary managers, rather than headquarters, were respondents.

This paper is based on empirical data from seven countries: Austria, Denmark, Finland, Germany, Norway, Sweden and the UK. All countries are located in the northern part of Europe. The four Nordic countries and Austria are relatively small, while Germany and the UK are among the largest in Europe. Approximately 80 percent of the questionnaires were answered by subsidiary executive officers, while financial managers, marketing managers or controllers in the subsidiary answered the remaining 20 percent. The response rate varies between 20 (UK) and 55 percent (Sweden), depending on the country of investigation. The quality of the data is quite high with a general level of missing values of not more than 5 percent.

As shown in Table 2.2, the total sample covers information on 2,107 subsidiaries, comprising all kinds of subsidiaries in all fields of business. Among countries, the sample size ranges from 202 (UK) to 530 (Sweden). With the exception of Sweden, the size of the sample is rather similar in the six countries. The average number of employees in subsidiaries is 742 and the median is 102 . Within the five smaller countries the average size of the subsidiaries are very similar, while Germany and UK — due to larger market sizes — comprise substantially larger subsidiaries.

\footnotetext{
**** Insert Table 2.2 about here $* * * *$
}

\subsubsection{Construct analysis}

The hypotheses are tested in a LISREL model that allow for simultaneous formation of underlying constructs (the measurement model) and test of structural relationships among these constructs (the structural model). The validity of LISREL models is estimated by the validity of the entire model, i.e., by the nomological validity. But before estimating the nomological validity of the model, with the causal relations specified, it is important to judge the convergent validity, i.e. the homogeneity 
of the constructs included in the model, and the discriminant validity, i.e., to what extent the constructs are independent. First, we will describe the operationalization of the constructs included and, then we will evaluate the different forms of validity. The three drivers of subsidiary development are latent constructs (underlying and not directly measurable) and are therefore measured as reflective measures, while the three dimensions of subsidiary development are manifest dimensions and is therefore measured as formative measures.

\section{Parent company drivers}

The parent company drivers mirror the discretion granted to the focal subsidiary by the parent firm. It may be the decision rights granted to the subsidiary on issues of strategic importance for the subsidiary. Based on the scale developed by Roth and Morison (1992), respondents were asked to identify the level at which certain decisions were made, where $1=$ corporate level (HQ), $2=$ divisional level and 3=subsidiary level. Decisions were as follows: entering new markets in host country; entering foreign markets; introduction of new products/services. Taken together these three items indicate the degree of decision rights granted to the subsidiary. The higher the value the more decision rights is granted.

\section{Host country drivers}

Host country drivers reflect the dynamism of the local business environment. Building on the main elements of Porter's (1990) diamond model, respondents were asked to assess the business environment in which they compete along three dimensions: availability of supply material; quality of suppliers; and demanding customers. The three items are measured on a 7-point Likert-type scale from 1 (very low) to 7 (very high). Together these three host country factors indicate to what extent the subsidiaries get dynamic impulses from the local environment (i.e. the external network of suppliers and customers).

\section{Subsidiary drivers}

This construct is measuring the focal subsidiary's own initiative and effort in upgrading the activities and competencies. For each of the six activities: development, production of goods and services, marketing/sales, logistics/distribution, purchasing, and HRM, respondents were asked to 'indicate the level of own investments for the past three years'. We chose a 3-year time frame to eliminate single-year fluctuations. All six items were measured on a 7-point Likert-type scale $(1=$ 
very limited and $7=$ very large). Taken together the items are forming a construct for the level of own subsidiary initiative.

\section{Scope and competence}

In line with Benito et. al (2003) scope and level of competence are manifest variables and, therefore, measured as formative measures. The two variables were operationalized as follows:

$$
\text { Scope of tasks }=\sum \mathrm{a}_{\mathrm{i}}
$$

where $a_{\mathrm{i}}=$ any given activity $i$ (development, production of goods or services, marketing/sales, logistic/distribution, purchasing, HRM) undertaken by a given subsidiary. Since it takes a value of 1 if an activity is performed, and 0 otherwise, the variable simply sums up the number of activities. Hence, the values range from 1 (i.e., a single-activity subsidiary) to 6 (i.e., the whole range of tasks is carried out).

$$
\text { Level of competence }=\sum \mathrm{c}_{\mathrm{i}} / \sum_{\mathrm{a}_{\mathrm{i}}}
$$

where $c_{i}$ is a measure of the level of competence of the subsidiary in performing a given activity $i$, as perceived by the subsidiary managers on a 7-point Likert-type scale (1=weak competence and $7=$ very strong competence). Since the level of competence indicator $c_{i}$ is counted only for activities $a_{i}$ actually undertaken by the focal subsidiary, it provides a measure of the average overall level of competence of that subsidiary.

\section{Level of Interdependence}

Reflects the extent to which the focal subsidiary is integrated in the MNC network i.e. how dependent other MNC-units are on the focal subsidiary and vice versa. The respondents were asked to assess to what extent other MNC-units where dependent on them: "What would be the consequences for other units in the Foreign Company if they no longer had access to the competencies of the subsidiary?" ( $1=$ no consequences, $7=$ very significant consequences $)$. In a similar vein, the subsidiary dependence on other MNC units was captured by the following question: "What would be the consequences for the subsidiary if it no longer had access to the competencies of other MNC units?" (1=no consequences, 7=very significant consequences). Taken together, these two items measure the level of interdependence between the focal subsidiary and other MNC units. 
A measurement model was created in order to assess convergent and discriminant validity of the three reflective measures. In Table 2.3 , convergent validity is judged by the $\mathrm{R}^{2}$-values measuring the strength of the linear relationships, the t-values (a significance test of each relationship in the model), and the factor loading for each indicator (Jöreskog and Sörbom, 1993). The constructs in this LISREL model all have good convergent validity, i.e. they are homogeneous constructs. As can be seen in Table 2.3, the strength of the linearity in relations between constructs and items are in all cases very strong (all $\mathrm{R}^{2}$-values are above the usual threshold of 0.20 ), which is also a reflection of the very large data set of more than 2.100 observations. From Table 2 we can conclude that the tvalues for all items are highly significant (all above 16) and that their (standardized) factors loadings are strong (all above 0.39).

**** Insert Table 2.3 about here $* * * *$

The second step in the analytical process was to form the structural model by specifying the causal relations in accordance with the proposed model. We tested single causal relations with $\mathrm{t}$-values and factor loadings between the constructs in the model. The Chi-square test statistic is frequently used to evaluate the performance of the entire model, i.e. whether the model is significantly different from the data (nomological validity). However, as a measure of fit the Chi-square has drawbacks limiting its use in this study. Thus, Bentler and Bonett (1980) have made the point that the Chisquare statistic - being a function of the sample size - is very sensitive to large sample sizes. Consequently, different alternative measure has been proposed. The two goodness-of-fit indicies, GFI (goodness-of-fit index) and AGFI (adjusted goodness-of-fit index) are measuring how closely the model fits the data by comparing the predicted and observed covariance matrices. In general, one considers a 0.9 level of GFI and AGFI as satisfactory, and a 0.8 level as the minium acceptable for a model (Bentler and Bonett, 1980). A related measure is the Norm Fit Index (NFI), which is interpreted as the percentage of variance in the data that the model is explaining (similar to Rsquare in OLS-models). As this study applies a very large sample of more than 2.100 observations the Chi-square statistics is of limited use and instead we apply the alternative measures of goodness-of-fit of the model. 


\subsection{Results}

Through repeated iterations a LISREL analysis proceeds with the fine-tuning of the model to obtain a more coherent representation of the empirical data. The purpose of the LISREL analysis is to arrive at and confirm a model consisting of specified causal relations. The first step was to test all possible causal relationships simultaneously. However, some of the relations turned out to be insignificant and after omitting the insignificant relations we arrived at the structural model shown in Figure 2.3. The figures given are standardized factor loadings of causal relations with t-values in parentheses.

**** Insert Figure 2.3 about here $* * * *$

The values of GFI and AGFI are 0.92 and 0.88 , respectively, and therefore well above the minimum level (of 0.8), suggesting an acceptable fit with the data (The Chi-square value is $1755 \mathrm{df}=75$ with $\mathrm{p}$ $<0.01)$. The NFI is 0.73 indicating that the model is able to explain almost three fourth of the variance in the data, which is very satisfactory.

It turns out that subsidiary initiative is positively related to all three dimensions of subsidiary development and, in particularly, for the scope of activities with a standardized coefficient of 0.43 . The local business environment is only having a significant relation to the level of competences indicating that the local dynamism in the business environment is an important source of upgrading of subsidiary competences. Headquarters granting of decision rights to the subsidiary is having a positive effect on the scope of subsidiary activities, but a significant negative effect on the extent to which the subsidiary is integrated in the internal MNC-network.

When allowing for correlations in the model among the three drivers it appear that both headquarter granting decision rights and local business environment are (highly) significantly correlated with subsidiary initiative indicating that they have a strong indirect effect on subsidiary development going through the influence on own subsidiary initiatives.

Furthermore, scope of activities is negatively correlated with the level of competences giving support to the argument that breadth of subsidiary activities often comes at the cost of depth in these activities. This implies that the subsidiaries with high level of competences typically will be 
relatively narrow in their scope, while subsidiaries with broader scope tend to have lower average level of competence for the activities they are carrying out.

Surprisingly, we don't find a significant correlation between level of competence and level of interdependence as was expected. The reason could be that subsidiaries in some cases develop high levels of competence in the interaction with external counterparts, which is of very little use in other MNC-units as it is developed in a different context. The implication is that high levels of competence will only be associated with high levels of interdependence when the competence is useful and important for other MNC-units. At the core of this argument is the distinction between autonomous subsidiaries that may have high competences but of little use in other MNC-units and Centres of Excellence with high competences that are used in other MNC-units (Holm and Pedersen, 2000).

\subsection{Discussion and policy implications}

The literature on subsidiary development identifies three drivers affecting the subsidiary development process (here operationalized by the dimensions of scope, competences and interdependence): parent company drivers, host country drivers and subsidiary drivers.

Parent companies can play an active role, in the sense that a decision can be taken to provide a subsidiary a formal responsibility for a certain task. Such a decision can be based on certain identified potential of the subsidiary. In contrast to this, the headquarters role can also be more indirect. Over time, the activities of the subsidiary within a certain area are recognized at headquarters, and eventually the subsidiary is given the responsibility for that area. In the latter case, the main driving force in subsidiary development is the subsidiary entrepreneurship, which is eventually confirmed by the headquarter.

The results indicate that headquarters mainly has discretion over the scope of subsidiary activities and the extent to which subsidiaries are integrated in the MNC-network, while they have less influence on the level of subsidiary competence. Interestingly, it seems like the granting of more decision rights to the subsidiary expand the scope of activities, but at the same time have a negative effect on the degree of interdependence, meaning that the subsidiary will tend to isolate themselves more from other MNC-units. In that sense the parent company drivers may seem to have a double 
character, enhancing one dimension of subsidiary development (scope of activities), but at the cost of another dimension (level of interdependence).

Obviously, the most important driver of subsidiary development is the subsidiaries own entrepreneurial initiatives for upgrading of their resources and competences. In contract to the effect of parent company drivers, the subsidiary drivers have a uniform positive effect on all three dimensions of subsidiary development.

The main direct effect of policy-makers goes through creation of a dynamic local business environment, which has a strong positive influence on the level of competence. With a coefficient of 0.16 the local business environment is almost as important as own subsidiary initiatives in upgrading the level of competences. However, the direct effect of policy-makers on scope of activities and level of interdependence is very limited.

It bring out some important findings for policy-makers where the most significant is that subsidiaries indeed has some freedom to form their own development path, so it is worthwhile creating a supportive business environment for their upgrading and development. A prudent policy towards 'monitoring' MNC subsidiaries requires an understanding of their development dynamics.

\section{References}

Bartlett, C. and S. Ghoshal (1989). Managing Across Borders." The Transnational Solution. Boston, MA: Harvard Business School Press, 1989.

Benito, G.R.G., B. Grøgaard and R. Narula (2003). Environmental influences on MNE subsidiary roles: economic integration and the Nordic countries. Journal of International Business Studies, 34 (5): 443-456

Bentler P.M. and D.G. Bonett (1980). Significance tests and goodness of fit in the analysis of covariance structures. Psychological Bulletin, 88: 588-606.

Birkinshaw, J. and N. Hood (1998a). 'Multinational subsidiary evolution: capability and charter change in foreign-owned subsidiary companies'. Academy of Management Review, 23(4): 773-795. 
Birkinshaw, J. and N. Hood (eds) (1998b), Multinational Corporate Evolution and Subsidiary Development. London: Macmillan.

Buckley P. and M. Casson (1976). The Future of Multinational Enterprises. London: Macmillan.

Doz, Y. L.. J. Santos and P. Williamson (2001). From global to metanational - How companies win in the knowledge economy. Harvard Business School Press: New York.

Etemad H. and L. S. Dulude (eds) (1986). Managing the Multinational Subsidiary. Response to Environmental Changes and to Host nation R\&D Policies. London: Croom Helm.

Forsgren, M. and T. Pedersen (1998). 'Centres of Excellence in Multinational Networks'. In Birkinshaw and Hood (1998b).

Foss, N. and K. Foss (2002). Authority and discretion: Tensions, delegation and implications for new organizational forms. Paper presented at the 2001 LINK conference, Copenhagen, Denmark.

Gupta, A.K. and V. Govindarajan (1991). 'Knowledge Flows and the Structure of Control Within Multinational Corporations'. Academy of Management Review, 16 (4): 768-792.

Gupta, A.K. and V. Govindarajan (1994). 'Organizing for knowledge flows within MNCs'. International Business Review, 3(4): 443-457.

Hennart, J.F. (1982). A theory of the Multinational Enterprise. Ann Arbor: University of Michigan.

Holm, U. and T. Pedersen, T. (eds.) (2000). The emergence and impact of MNC centers of excellence. London: Macmillan.

Hymer, S. (1960). The International Operations of National Firms a Study of Foreign Direct Investment. Cambridge: MIT Press (1976).

Jarillo, J.C. and J.I. Martinez (1990). 'Different Roles for Subsidiaries: The case of Multinational Corporations in Spain'. Strategic Management Journal, 11 (7): 501-512.

Jöreskog, K.G. and D. Sörbom (1993). LISREL 8: Structural Equation Modelling with SIMPLIS command language. Chicago: Scientific Software International.

Kogut, B. (1993). 'Learning, or the Importance of being Inert: Country Imprinting and International Competition'. In S. Ghoshal, and D. E. Westney (eds). Organization Theory and the Multinational Corporation. London: Macmillan Press Ltd.

Kuemmerle, W. (1999). 'The drivers of foreign direct investment into research and development: an empirical investigation. Journal of International Business Studies, 30(1): 1-24.

Malnight, T.W. (1996). 'The Transition from Decentralized to Network-based MNC Strucutres: An Evolutionary Perspective'. Journal of International Business Studies, 27 (1): 43-65 
Nohria, N. and S. Ghoshal (1994). 'Differentiated fit and shared values: Alternatives for managing headquarters-subsidiary relations'. Strategic Management Journal, 15(6): 491-502.

Pfeffer, J. and G.R. Salancik (1978). The external control of organizations: A resource dependency perspective. New York: Harper and Row.

Porter, M.E. (1990). The Competitive Advantage of Nations. New York: Free Press.

Roth, K. and A. Morrison (1992). 'Implementing global strategy: characteristics of global subsidiary mandates'. Journal of International Business Studies, 23(4): 715-736.

White, R.E. and T.A. Poynter (1984). 'Strategies for Foreign-Owned Subsidiaries in Canada'. Business Quarterly, 48(4): 59-69. 
Figure 2.1. Three factors driving subsidiary development

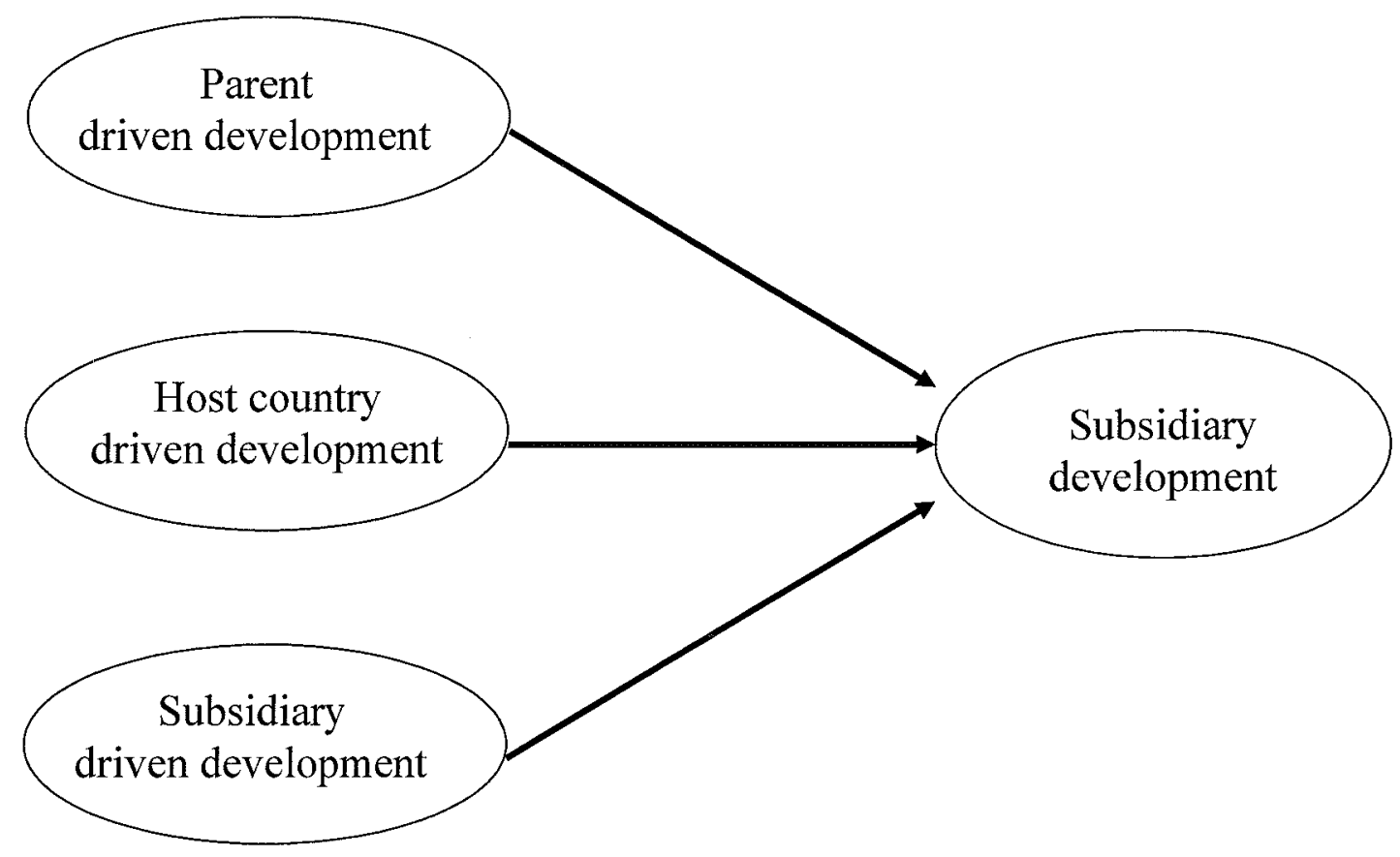


Figure 2.2. Model of subsidiary development

Drivers

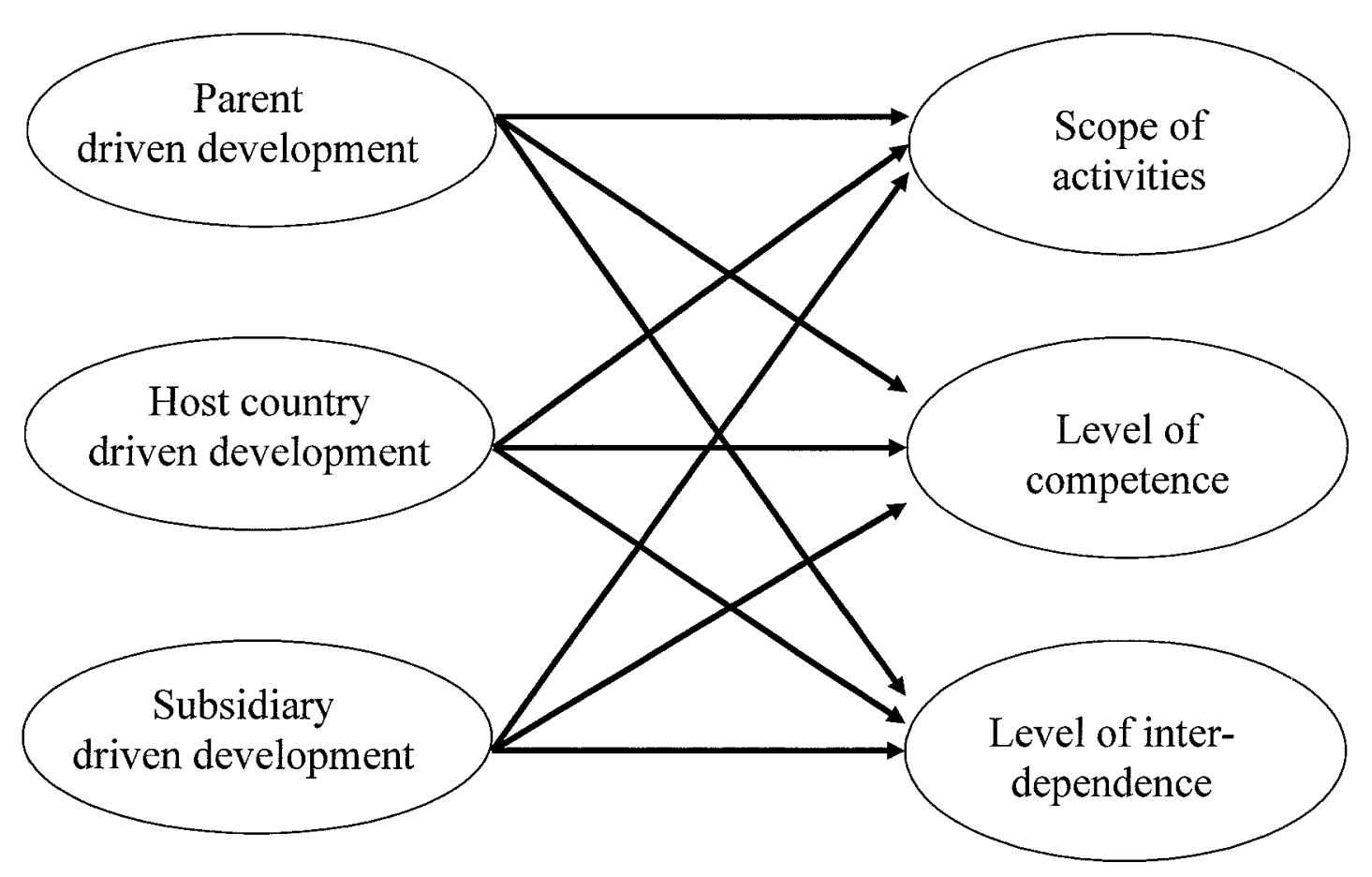


Figure 2.3. LISREL model of Subsidiary Development

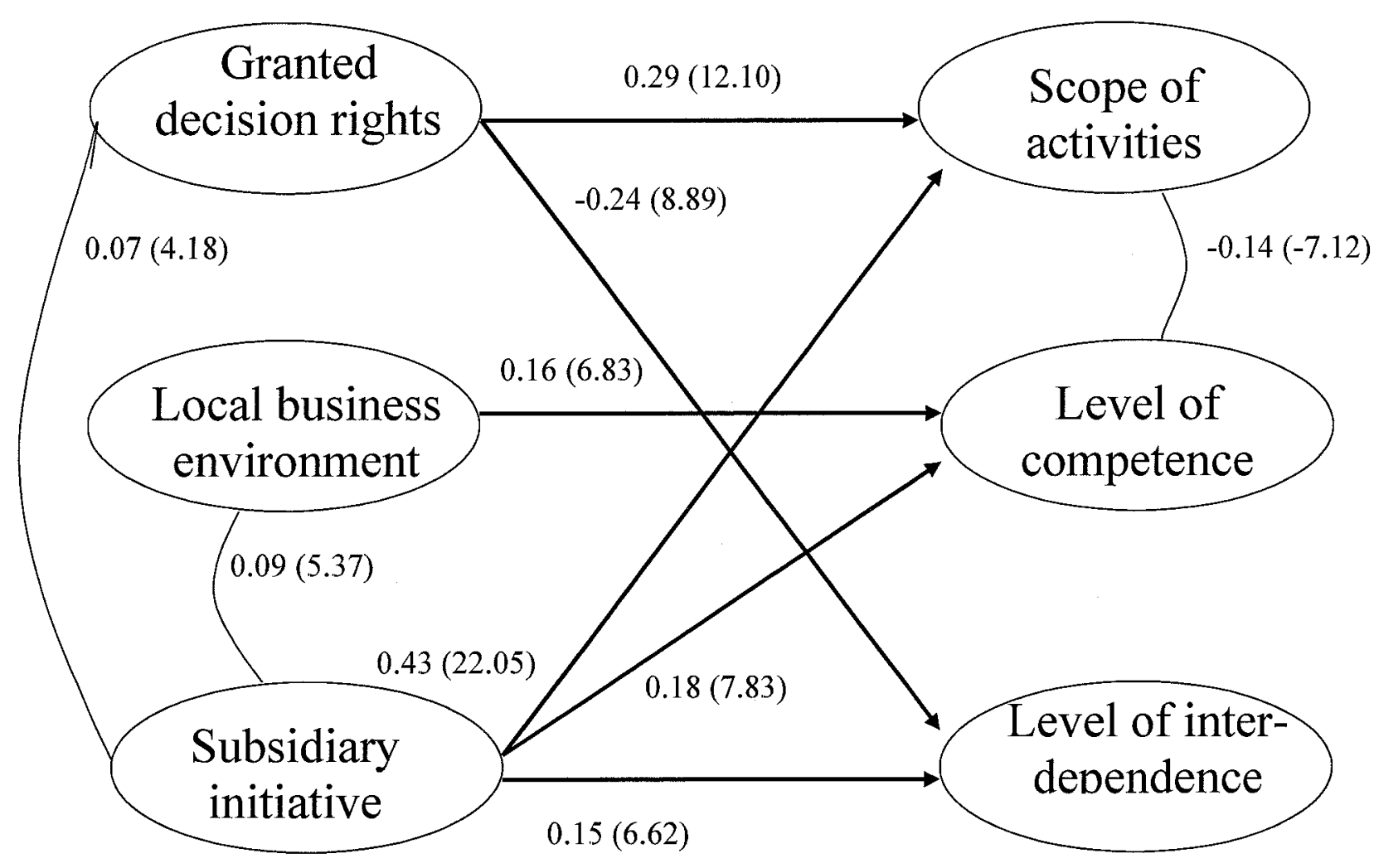


Table 2.1. Three streams of research on subsidiary management

\begin{tabular}{|c|c|c|c|}
\hline & $\begin{array}{l}\text { HQ-subsidiary } \\
\text { relationship }\end{array}$ & Subsidiary role & $\begin{array}{c}\text { Subsidiary } \\
\text { development }\end{array}$ \\
\hline Focus on research & $\begin{array}{l}\text { Aspects of dyadic } \\
\text { relationship between } \\
\text { subsidiary and HQ }\end{array}$ & $\begin{array}{l}\text { Internal, corporate and } \\
\text { environmental factors } \\
\text { explaining different } \\
\text { subsidiary roles }\end{array}$ & $\begin{array}{c}\text { Changes in role and } \\
\text { activities of subsidiary } \\
\text { over time }\end{array}$ \\
\hline $\begin{array}{l}\text { Assumptions about } \\
\text { nature of } M N C\end{array}$ & $\begin{array}{l}\text { Hierarchy: subsidiaries } \\
\text { are controlled by HQ }\end{array}$ & \multicolumn{2}{|c|}{$\begin{array}{l}\text { Heterarchy/network: subsidiaries have different } \\
\text { roles and have relationships with multiple units } \\
\text { inside/outside the firm }\end{array}$} \\
\hline Research approach & \multicolumn{2}{|c|}{ Cross-sectional / static } & $\begin{array}{c}\text { Longitudinal / } \\
\text { dynamic }\end{array}$ \\
\hline $\begin{array}{l}\text { Theoretical } \\
\text { foundations }\end{array}$ & $\begin{array}{l}\text { Transaction cost } \\
\text { theory, contingency } \\
\text { theory }\end{array}$ & Social network theory & $\begin{array}{l}\text { Evolutionary theory, } \\
\text { resource-based theory }\end{array}$ \\
\hline
\end{tabular}

Based on Birkinshaw and Hood, 1998b, p. 5. 
Table 2.2. Sample size and subsidiary employees in the different countries

\begin{tabular}{|l|c|c|}
\hline COUNTRY & SAMPLE SIZE & SUBSIDIARY EMPLOYEES (mean) \\
\hline Austria & 313 & 318 \\
\hline Denmark & 308 & 284 \\
\hline Finland & 238 & 200 \\
\hline Germany & 254 & 1.574 \\
\hline Norway & 262 & 130 \\
\hline Sweden & 530 & 244 \\
\hline UK & 202 & 3.787 \\
\hline \multicolumn{1}{|c|}{ Total } & $\mathbf{2 . 1 0 7}$ & $\mathbf{7 4 2}$ \\
\hline
\end{tabular}


Table 2.3 Constructs and items of reflective measures

\begin{tabular}{|c|c|c|c|}
\hline Constructs and items & $\begin{array}{l}\text { Factor } \\
\text { loading* }\end{array}$ & t-value & $\mathrm{R}^{2}$-value \\
\hline \multirow{4}{*}{$\begin{array}{l}\text { Granted decision rights } \\
\text { Decisions on entering new markets in host country } \\
\text { Decisions on entering markets abroad } \\
\text { Decisions on introduction of new products/services }\end{array}$} & & & \\
\hline & 0.54 & 20.65 & 0.29 \\
\hline & 0.62 & 23.59 & 0.38 \\
\hline & 0.42 & 16.32 & 0.22 \\
\hline \multicolumn{4}{|l|}{ Local business environment } \\
\hline \multirow{3}{*}{$\begin{array}{l}\text { Availability of supply material } \\
\text { Quality of suppliers } \\
\text { Demanding customers }\end{array}$} & 0.65 & 24.80 & 0.42 \\
\hline & 0.86 & 32.99 & 0.75 \\
\hline & 0.39 & 16.56 & 0.23 \\
\hline \multicolumn{4}{|l|}{ Subsidiary initiative } \\
\hline \multirow{3}{*}{$\begin{array}{l}\text { Investments in development } \\
\text { Investments in production of goods and services } \\
\text { Investments in marketing/sales }\end{array}$} & 0.41 & 19.19 & 0.25 \\
\hline & 0.43 & 20.18 & 0.26 \\
\hline & 0.55 & 27.88 & 0.30 \\
\hline \multirow{3}{*}{$\begin{array}{l}\text { Investments in logistics/distribution } \\
\text { Investments in purchasing }\end{array}$} & 0.67 & 38.16 & 0.45 \\
\hline & 0.75 & 45.97 & 0.56 \\
\hline & 0.69 & 39.80 & 0.47 \\
\hline
\end{tabular}

* all factor loadings are highly significant at $\mathrm{p}<0.01$ with $\mathrm{t}$-value above 16 . 


\section{SMG - Working Papers www.cbs.dk/smg 2003}

2003-1: Nicolai J. Foss, Kenneth Husted, Snejina Michailova, and Torben Pedersen: Governing Knowledge Processes: Theoretical Foundations and Research Opportunities.

2003-2: Yves Doz, Nicolai J. Foss, Stefanie Lenway, Marjorie Lyles, Silvia Massini, Thomas P. Murtha and Torben Pedersen: Future Frontiers in International Management Research: Innovation, Knowledge Creation, and Change in Multinational Companies.

2003-3: Snejina Michailova and Kate Hutchings: The Impact of In-Groups and OutGroups on Knowledge Sharing in Russia and China CKG Working Paper.

2003-4: Nicolai J. Foss and Torben Pedersen : The MNC as a Knowledge Structure: The Roles of Knowledge Sources and Organizational Instruments in MNC Knowledge Management CKG Working Paper.

2003-5: Kirsten Foss, Nicolai J. Foss and Xosé H. Vázquez-Vicente: “Tying the Manager's Hands": How Firms Can Make Credible Commitments That Make Opportunistic Managerial Intervention Less Likely CKG Working Paper.

2003-6: Marjorie Lyles, Torben Pedersen and Bent Petersen: Knowledge Gaps: The Case of Knowledge about Foreign Entry.

2003-7: Kirsten Foss and Nicolai J. Foss: The Limits to Designed Orders: Authority under "Distributed Knowledge" CKG Working Paper.

2003-8: Jens Gammelgaard and Torben Pedersen: Internal versus External Knowledge Sourcing of Subsidiaries - An Organizational Trade-Off.

2003-9: Kate Hutchings and Snejina Michailova: Facilitating Knowledge Sharing in Russian and Chinese Subsidiaries: The Importance of Groups and Personal Networks Accepted for publication in Journal of Knowledge Management.

2003-10: Volker Mahnke, Torben Pedersen and Markus Verzin: The impact of knowledge management on MNC subsidiary performance: the role of absorptive capacity CKG Working Paper.

2003-11: Tomas Hellström and Kenneth Husted: Mapping Knowledge and Intellectual Capital in Academic Environments: A Focus Group Study Accepted for publication in Journal of Intellectual Capital CKG Working Paper.

2003-12: Nicolai J Foss: Cognition and Motivation in the Theory of the Firm: Interaction or "Never the Twain Shall Meet"? Accepted for publication in Journal des Economistes et des Etudes Humaines CKG Working Paper.

2003-13: Dana Minbaeva and Snejina Michailova: Knowledge transfer and expatriation practices in MNCs: The role of disseminative capacity.

2003-14: Christian Vintergaard and Kenneth Husted: Enhancing selective capacity through venture bases. 


\section{4}

2004-1: Nicolai J. Foss: Knowledge and Organization in the Theory of the Multinational Corporation: Some Foundational Issues

2004-2: Dana B. Minbaeva: HRM practices and MNC knowledge transfer

2004-3: Bo Bernhard Nielsen and Snejina Michailova: Toward a phase-model of global knowledge management systems in multinational corporations

2004-4: Kirsten Foss \& Nicolai J Foss: The Next Step in the Evolution of the RBV: Integration with Transaction Cost Economics

2004-5: Teppo Felin \& Nicolai J. Foss: Methodological Individualism and the Organizational Capabilities Approach

2004-6: Jens Gammelgaard, Kenneth Husted, Snejina Michailova: Knowledge-sharing Behavior and Post-acquisition Integration Failure

2004-7: Jens Gammelgaard: Multinational Exploration of Acquired R\&D Activities

2004-8: Christoph Dörrenbächer \& Jens Gammelgaard: Subsidiary Upgrading? Strategic Inertia in the Development of German-owned Subsidiaries in Hungary

2004-9: Kirsten Foss \& Nicolai J. Foss: Resources and Transaction Costs: How the Economics of Property Rights Furthers the Resource-based View

2004-10: Jens Gammelgaard \& Thomas Ritter: The Knowledge Retrieval Matrix: Codification and Personification as Separate Strategies

2004-11: Nicolai J. Foss \& Peter G. Klein: Entrepreneurship and the Economic Theory of the Firm: Any Gains from Trade?

2004-12: Akshey Gupta \& Snejina Michailova: Knowledge Sharing in Knowledge-Intensive Firms: Opportunities and Limitations of Knowledge Codification

2004-13: Snejina Michailova \& Kate Hutchings: Knowledge Sharing and National Culture: A Comparison Between China and Russia

\section{5}

2005-1: Keld Laursen \& Ammon Salter: My Precious - The Role of Appropriability Strategies in Shaping Innovative Performance

2005-2: Nicolai J. Foss \& Peter G. Klein: The Theory of the Firm and Its Critics: A Stocktaking and Assessment

2005-3: Lars Bo Jeppesen \& Lars Frederiksen: Why Firm-Established User Communities Work for Innovation: The Personal Attributes of Innovative Users in the Case of Computer-Controlled Music

2005-4: Dana B. Minbaeva: Negative Impact of Hrm Complementarity on Knowledge Transfer in Mncs

2005-5: Kirsten Foss, Nicolai J. Foss, Peter G. Klein \& Sandra K. Klein: Austrian Capital Theory and the Link Between Entrepreneurship and the Theory of the Firm 
2005-1: Nicolai J. Foss: The Knowledge Governance Approach

2005-2: Torben J. Andersen: Capital Structure, Environmental Dynamism, Innovation Strategy, and Strategic Risk Management

2005-3: Torben J. Andersen: A Strategic Risk Management Framework for Multinational Enterprise

2005-4: Peter Holdt Christensen: Facilitating Knowledge Sharing: A Conceptual Framework

2005-5 Kirsten Foss \& Nicolai J. Foss: Hands Off! How Organizational Design Can Make Delegation Credible

2005-6 Marjorie A. Lyles, Torben Pedersen \& Bent Petersen: Closing the Knowledge Gap in Foreign Markets - A Learning Perspective

2005-7 Christian Geisler Asmussen, Torben Pedersen \& Bent Petersen: How do we capture "Global Specialization" when measuring firms' degree of internationalization?

2005-8 Kirsten Foss \& Nicolai J. Foss: Simon on Problem-Solving: Implications for New Organizational Forms

2005-9 Birgitte Grøgaard, Carmine Gioia \& Gabriel R.G. Benito: An Empirical Investigation of the Role of Industry Factors in the Internationalization Patterns of Firms

2005-10 Torben J. Andersen: The Performance and Risk Management Implications of Multinationality: An Industry Perspective

2005-11 Nicolai J. Foss: The Scientific Progress in Strategic Management: The case of the Resource-based view

2005-12 Koen H. Heimeriks: Alliance capability as a mediator between experience and alliance performance: An empirical investigation into the alliance capability development process

2005-13 Koen H. Heimeriks, Geert Duysters \& Wim Vanhaverbeke: Developing Alliance Capabilities: An Empirical Study

2005-14 JC Spender: Management, Rational or Creative? A Knowledge-Based Discussion 2006

2006-1: Nicolai J. Foss \& Peter G. Klein: The Emergence of the Modern Theory of the Firm

2006-2: Teppo Felin \& Nicolai J. Foss: Individuals and Organizations: Thoughts on a Micro-Foundations Project for Strategic Management and Organizational Analysis

2006-3: Volker Mahnke, Torben Pedersen \& Markus Venzin: Does Knowledge Sharing Pay? An MNC Subsidiary Perspective on Knowledge Outflows

2006-4: Torben Pedersen: Determining Factors of Subsidiary Development 